\title{
Seismicity of Mosul Dam Reservoir
}

\author{
Nabeel H. Al-Saigh \\ Dams and Water Resources Research Centre \\ Mosul University
}

(Received 29/11/2007, Accepted 30/6/2008)

\begin{abstract}
Seismic activity has been studied at Mosul dam reservoir for the period from March 1986 to December 1987. More than 250 micro-earthquakes of magnitude up to $3.2 \mathrm{ML}$ were observed, of which 18 - were located. Nearly all earthquake epicenters were located within a radius of less than $25 \mathrm{~km}$ from the dam site. Cluster of epicentres was observed in the eastern embankment of the reservoir. Most of the hypocenters were located between the ground-surface and $2 \mathrm{~km}$ of depth.

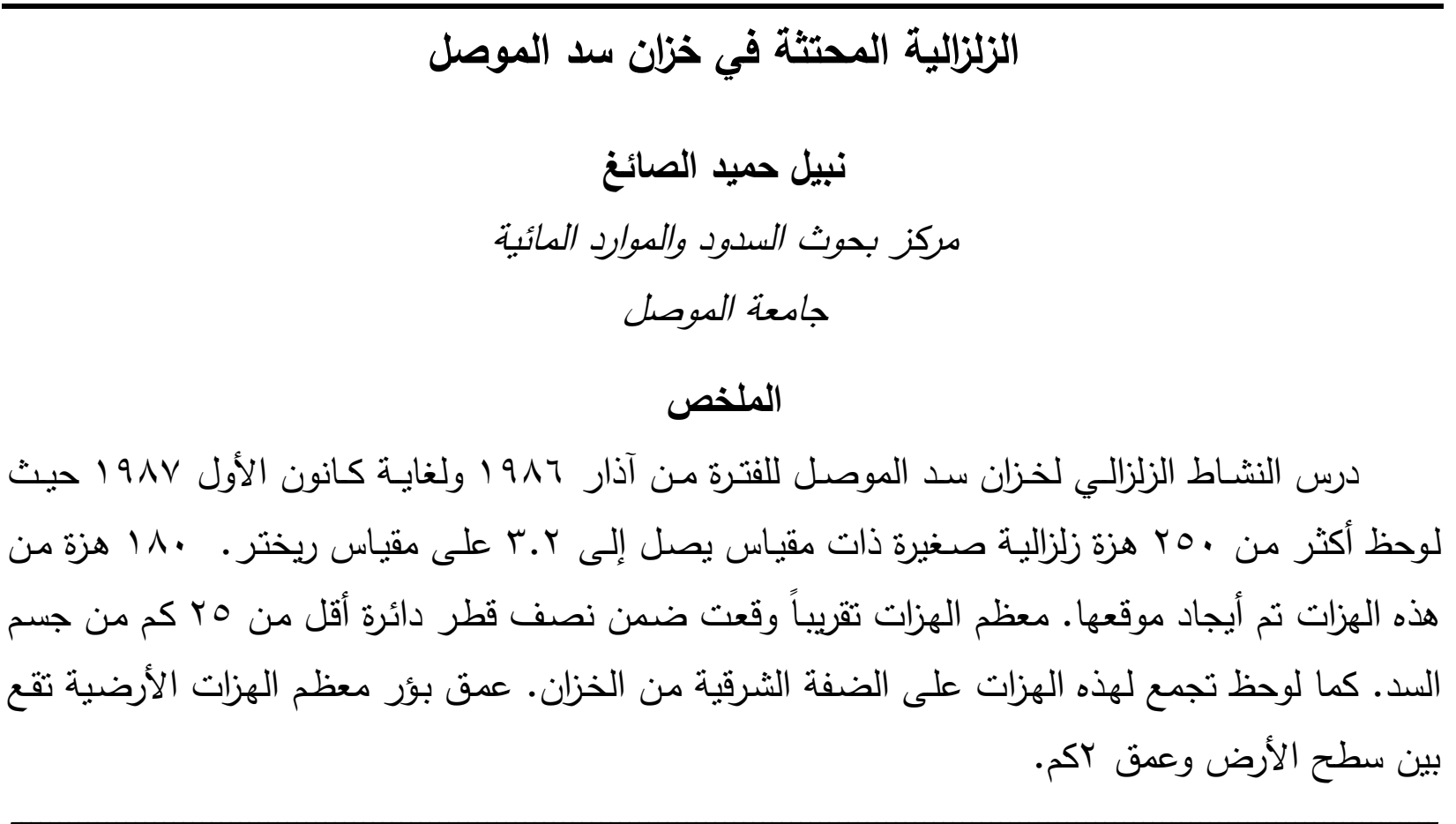

INTRODUCTION

In many places seismic activity has been related to the filling of large reservoirs (Simpson, 1976; Gupta and Rastogi, 1976; Gupta 2002).

Seismic activity has been noticed in the Mosul reservoir after starting the filling of the lake in June 1985. Mahmood, et al., (1988) using five seismographic network distributed around the lake identified 499 events during the period March 1986 to December 1987, however only 64 events had been located. The hypocenter's depth ranges between the surface level and $55 \mathrm{~km}$ deep.

It has been greatly believed that the effect of the reservoir can not be extended to generate seismicity at such depths. Great errors were expected in such location since it has been used graphical method for hypocenter determination besides using uniform $\mathrm{P}$ and S seismic velocity values for the area with no lateral or vertical inhomogenities. 
In this study the seismic activity has been studied in the area for the same monitoring period from March 1986 to December 1987. In this study, however, the earthquakes arrival times were re-picked from the seismic records. The earthquakes relocated by applying the HYPO71 program written by Lee and Lahr (1972) and using a crustal velocity model for the area suggested by Al-Saigh and Toffeq (1993).

\section{Geological and tectonic setting of the area}

The main exposure rocks in the study area are the Fat ha Formation (M. Miocene), while the Injana (U. Miocene), Miqdadia (Pliocene) and Pila-Spi (M. U. Eocene) Formations cover rest of the area (Fig.1).

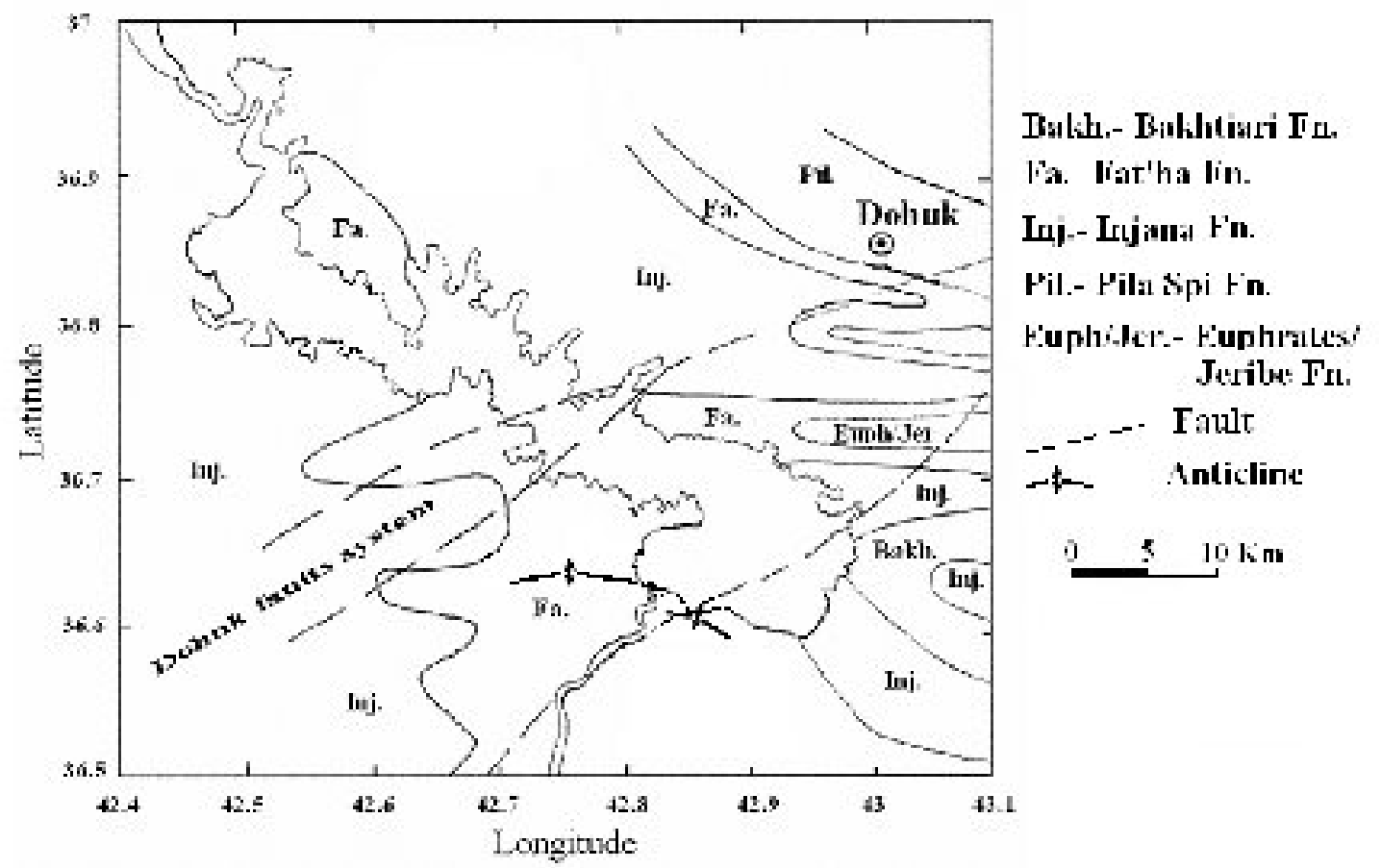

Fig. 1: Geological map of Mosul's dam lake (Modified from the Geological, 1986 and Tectonic maps of Iraq, 1984).

The dam site is bounded by two anticlines trending E-W; namely Tayarh and Butmah East anticlines. Tayarh anticline is located on the eastern side of the Tigris river. It is a small anticline of about $4 \mathrm{~km}$ long and $0.5 \mathrm{~km}$ wide. Butmah East anticline, on the other hand, is located on the western side of the river. It is about $12 \mathrm{~km}$ long and $3.5 \mathrm{~km}$ wide (Tawfiq and Domas, 1977).

The structure and stratigraphy of the southern part of Mosul reservoir have been deduced from seismic reflection profiles and deep boreholes information (Al-Saigh and Toffeq, 1993). Nine good reflectors, lying at depths range between $700 \mathrm{~m}$ and $7150 \mathrm{~m}$ below the surface level, have been identified. The lithology is dominated by carbonate sediments and the dominant fault trends in the area are NE-SW.

\section{Spatial distribution of seismic events}

More than 250 earthquakes were identified, of which 180 were located. Only events recorded on three or more seismic stations were considered. Most of the events, however, were recorded on three stations. This is due to very bad recording. During the first 
monitoring period the recording speed was $10 \mathrm{~mm} / \mathrm{min}$ and since March 1987 the speed increased to $60 \mathrm{~mm} / \mathrm{min}$. The relatively high noise level at three of the stations (BOT, REG, and AMR) made the determination of earthquake parameters very difficult. Moreover, most frequently, at least one of the five stations was out of operation during the monitoring period.

Figure (2) is a plan view showing the spatial distribution of earthquake epicenters in the area. Nearly all the epicenters were located within a radius of less than $25 \mathrm{~km}$ from the dam site. The majority of the epicenters were located in the lake region, in the area between the Dohuk faults system. The width of this zone is about $17 \mathrm{~km}$. However, the largest concentrations of epicenters were located on the eastern embankment of the lake between the two seismographic stations AMR and KHN. This part represents the deepest part of the reservoir.

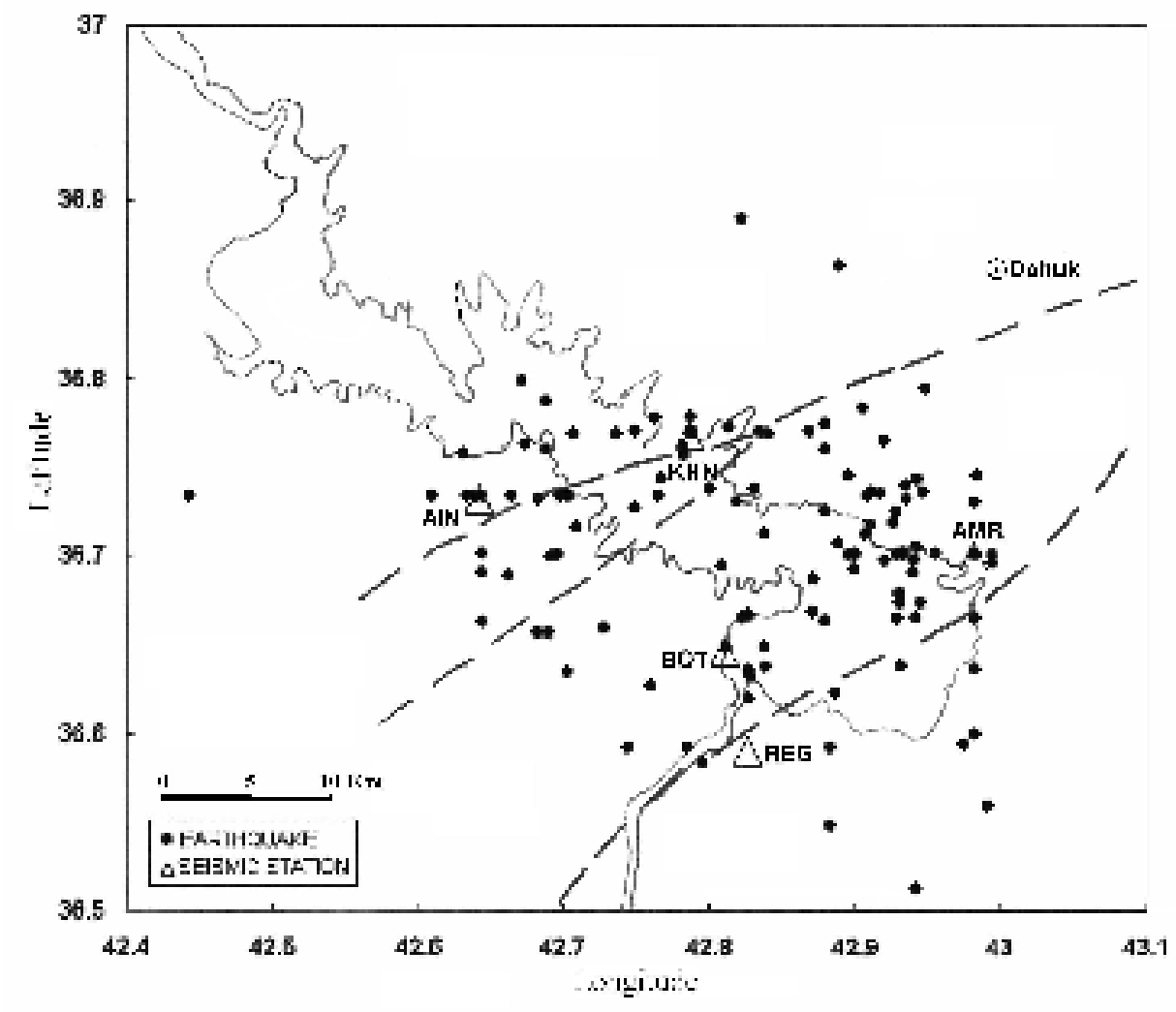

Fig. 2 Seismicity map of Mosul's reservoir for the period March 1986-December 1987.

Figure (3) is a vertical section showing the distribution of earthquake hypocenters with depth. Most of the hypocenters were located between the surface and $2 \mathrm{~km}$ deep. Very few were located between $2 \mathrm{~km}$ and $4.5 \mathrm{~km}$ deep.

\section{Reservoir level and earthquake frequency}

Because of instrumentation problems not all earthquakes could be located; hence the earthquake catalog shows fewer events and is not representative during the time period.

Filling of the reservoir started in June 1985. Figure 4 shows the monthly relationship between the reservoir water level and the number of induced earthquakes. 
There are obvious increases in seismicity following each of the yearly maxima in water level. The first highest water level was reached during the period of mid May to end of July 1986 which corresponds with maximum seismic activity. The activity continued to the end of October long after the fall off the lake level which occurred from August through December.
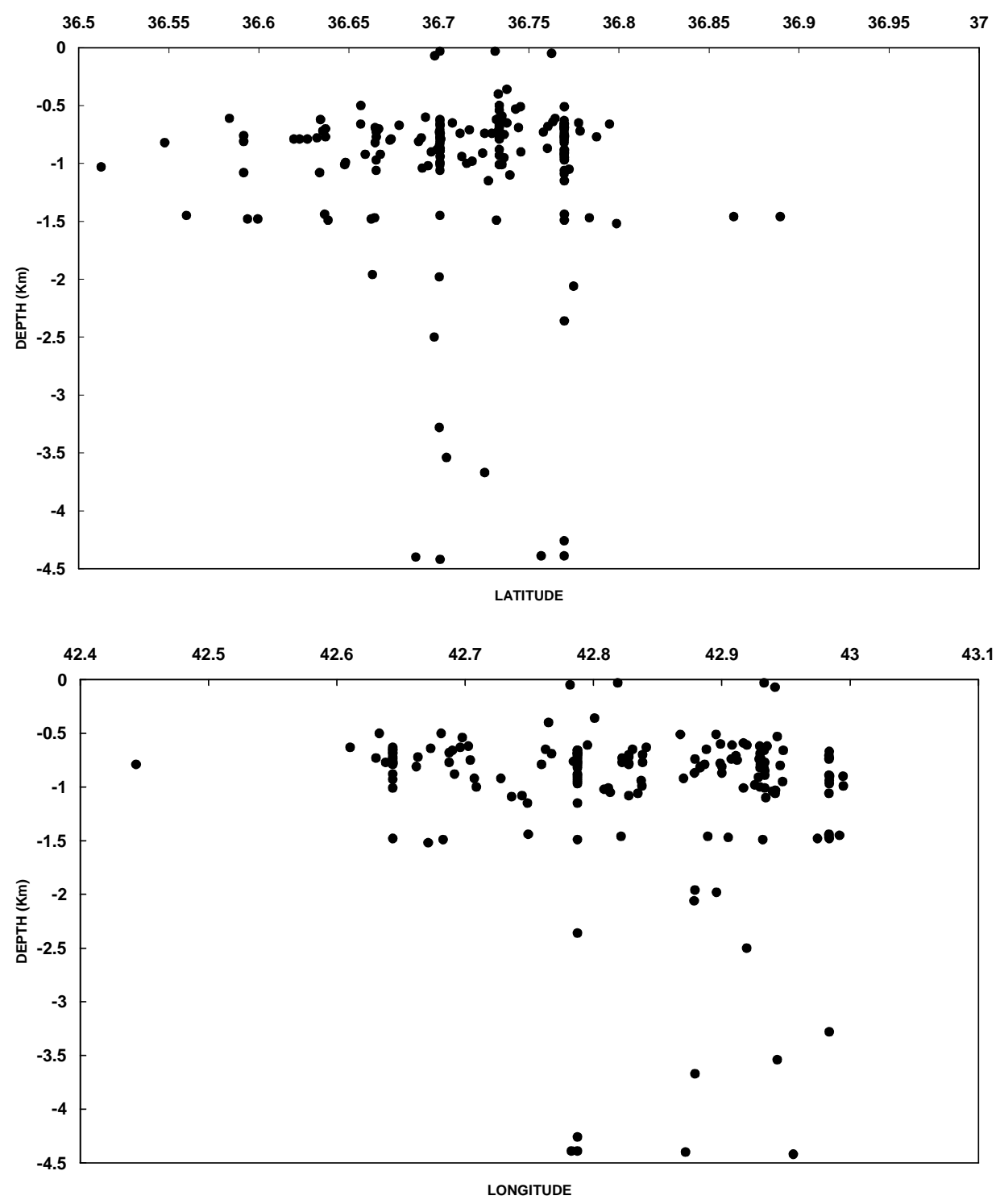

Fig. 3 Vertical distributions of earthquakes' hypocenters.

The second highest water level was reached during May and June 1987. The maximum seismicity, however, was during the period September to December with a time lag of about two months. There were two months delay between the peak reservoir level and the peak seismic activity. This is most probably due to the pore pressure effect.

A noticeable reduction of water level occurred during the period November 1986 and March 1987. Unfortunately the network was out of operation during this period to show the behavior of seismic activity during this period of reduction of water level. 
Figure 5 shows the cumulative number of observed and located earthquakes during the monitoring period. Linear regression fitting indicated that the average seismicity level was 0.6 and 0.4 events per day for the observed and located events respectively, during 1986, while it was 0.5 and 0.3 events per day during 1987.

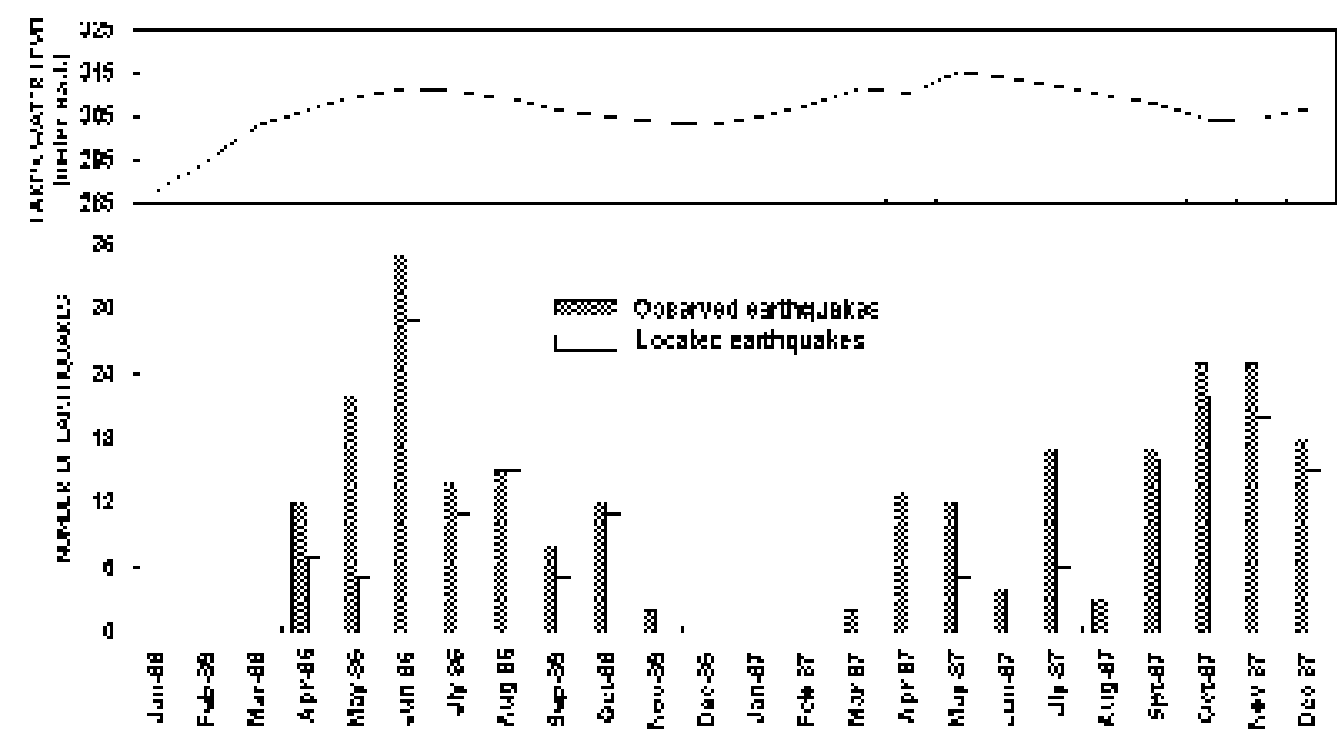

Fig. 4: The relationship between water level in the lake and the number of the observed and located earthquakes, during the monitoring period.
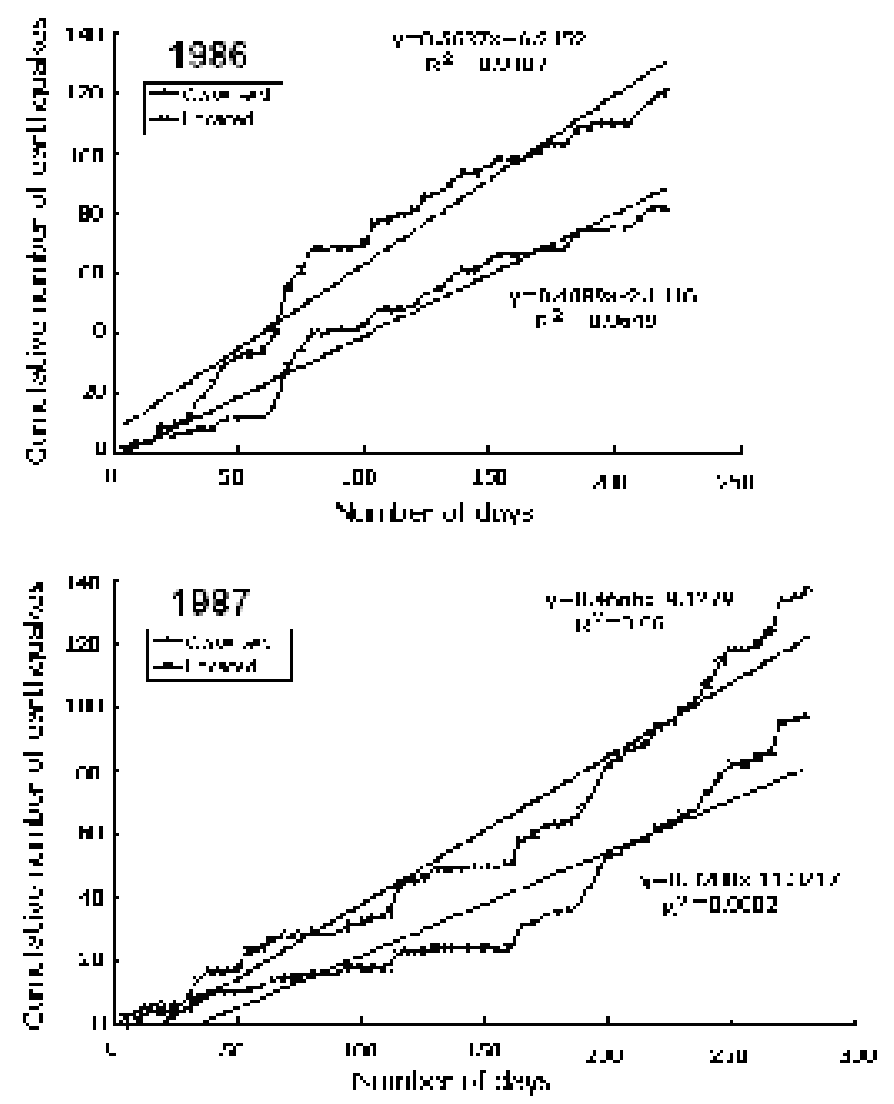

Fig. 5 Cumulative numbers of earthquakes against days of the year. 


\section{CONCLUSIONS}

Initiation of seismicity, correlation of seismicity with water levels, confinement of epicenters in the vicinity of the lake, shallow depths of hypocenters indicated that the seismicity is reservoir induced.

\section{ACKNOWLEDGEMENTS} records.

I am greatly indebted to the Directory of Mosul Dam for providing the seismic

\section{REFERENCES}

Al-Saigh, N. H. and Toffeq, I.N., 1993. Geological and Geophysical Study of the Southern Part of Saddam Reservoir. Iraqi Geological Journal, Vol.27, No.2, pp.150-161.

Directorate General of Geological Survey and Mineral Investigation, 1984. Tectonic Map of Iraq, Scale 1/1000,000. State Organization of Minerals.

Directorate General of Geological Survey and Mineral Investigation, 1986. Geological Map of Iraq, Scale 1/1000,000. State Organization of Minerals.

Gupta, H. K. and Rastogi, B.K., 1976. Dams and Earthquakes. Oxford, Elsevier Scientific Publishing Company.

Gupta, H.K., 2002. A Review of Recent Studies of Triggered Earthquakes by Artificial Water Reservoirs with Special Emphasis on Earthquakes in Koyan, India. EarthScience Review, pp.511-550

Lee, W.H.K. and Lahr, J.C., 1972. HYPO71, a Computer Program for Determining Hypocenter, Magnitude and First Motion Pattern of Local Earthquakes. U.S. Geological Survey, Open File Report, 100p.

Mahmood, D.S., Al-Salim, M.A., and Ayar, B.S., 1988. Monitoring, Recording and Analysis of Background Seismicity at Saddam Dam Area. Directorate of Saddam Dam Project, Internal Report, 23p.

Simpson, D.A., 1976. Induced Seismicity Associated with Water Reservoirs. Engineering Geology, Vol.10, pp.123-150.

Tawfiq, J.M., and Domas, J., 1977. The Regional Geological Mapping of DohukAinzalah Area. Unpublished Report. State Organization of Mineral Library, Baghdad, Report No.837. 